DOI: $10.14451 / 2.122 .46$

\title{
ФАКТОРНЫЙ АНАЛИЗ ВЛИЯНИЯ ИННОВАЦИОННОЙ СОСТАВЛЯЮЩЕЙ НА УРОВЕНЬ ЭКОНОМИЧЕСКОЙ БЕЗОПАСНОСТИ РЕГИОНОВ ПФО "
}

\author{
(c) 2018 Соколова Галина Николаевна \\ кандидат экономических наук, доцент \\ Чувашский государственный университет имени И.Н. Ульянова \\ 428015, Чувашская Республика, г. Чебоксары, пр-т Московский, д. 15 \\ E-mail: Galina_1980@list.ru \\ (C) 2018 Иванова Татьяна Валерьевна \\ кандидат экономических наук, доцент \\ Чувашский государственный университет имени И.Н. Ульянова \\ 428015, Чувашская Республика, г. Чебоксары, пр-т Московский, д. 15 \\ E-mail: ivanovatv85@mail.ru \\ (c) 2018 Ладыкова Татьяна Ивановна \\ кандидат экономических наук, доцент \\ Чувашский государственный университет имени И.Н. Ульянова \\ 428015, Чувашская Республика, г. Чебоксары, пр-т Московский, д. 15 \\ E-mail: ladykova@mail.ru \\ (c) 2018 Васильева Инесса Анатольевна \\ старший преподаватель \\ Чувашский государственный университет имени И.Н. Ульянова \\ 428015, Чувашская Республика, г. Чебоксары, пр-т Московский, д. 15 \\ E-mail: inka107@mail.ru
}

Статья посвящена исследованию влияния инновационной составляющей на уровень экономической безопасности регионов Приволжского федерального округа. Было выяснено, что основные факторы, влияющие на экономическую безопасность региона, включают экономическое развитие, социальное развитие и состояние финансовой сферы в регионе.

Ключевые слова: экономическая безопасность региона, инновационная деятельность, факторный анализ, социально-экономическое развитие.

Изучив положение инновационной деятельности регионов ПФО, и опираясь на интегральный индекс экономической безопасности, с помощью статистического метода изучения взаимосвязей между значениями переменных было определено, какие показатели инновационной деятельности в большей степени влияют на экономическую безопасность региона. В результате было выяснено, что к таким показателям относятся: численность персонала, занятого научными исследованиями и разработками, инновационной активности организаций и уровнем расходов на технологические инновации. На основании полученных значений были определены основные направлениями по повышению экономической безопасности регионов ПФО.

\section{Введение}

Экономическая безопасность государства и регионов во многом зависит от степени восприимчивости реального сектора экономики к инновациям. Вступление России на инновационный пути развития, связанный с формированием национальной инновационной системы, является важнейшим фактором роста конкурентоспособности страны и ее экономической безопасности. В этой связи, в практике управления стоит важная задача - определить направления решения основных проблем развития инновационной составляющей экономики страны и ее регионов. Вследствие этого, важнейшее значение приобретает влияние инновационной составляющей на уровень экономической безопасности регионов.

* Исследование выполнено при финансовой поддержке РФФИ № : 17-12-21011 
Анализ литературы по теме исследования показал, что проблемы влияния инноваций на уровень экономической безопасности до конца не исследованы. В источниках, посвященных определению сущности экономической безопасности прослеживается связь категорий «инновация» и «экономическая безопасность» [Кунцман, 2016, 44].

В рамках данной статьи мы будем исследовать влияние инновационной составляющей на уровень экономической безопасности регионов ПФО. Рассмотрим положение инновационной деятельности в ПФО в 2016 г. на основе данных Федеральной службы государственной статистики (табл. 1).

Сравнительный анализ приведенных показателей свидетельствует о том, что лидирующие позиции занимают такие регионы как Республика Татарстан, Нижегородская область, Самарская область и Республика Башкортостан.

Изучив теоретико-методологические аспекты экономической безопасности региона, были выявлены основные факторы, влияющие на экономическую безопасность региона, включающие [Соколова, Ладыкова, 2017, 107]: экономическое развитие, социальное развитие и состояние финансовой сферы в регионе.

По результатам проведенного расчета экономической безопасности регионов ПФО, были получены следующие значения интегрального коэффициента экономической безопасности в 2016 г. (табл. 2).

В рамках настоящего исследования проведем оценку влияния инновационной составляющей на уровень экономической безопасности регионов ПФО.

Для измерения влияния отдельных факторов инновационной составляющей на уровень экономической безопасности проведем факторный анализ по данным Росстата за 2016 год среди регионов ПФО.

Коэффициент корреляции будем рассчитывать на основе следующей формулы:

$$
r=\frac{\mathrm{n} \sum x y-\sum x \sum y}{\sqrt{n \sum x^{2}-\left(\sum x\right)^{2}}} \frac{}{* \sqrt{n \sum y^{2}-\left(\sum y\right)^{2}}}
$$

Где у - независимая переменная, т.е. интегральный коэффициент экономической безопасности региона; х1 - показатель количества организаций, выполнявших научные ИиР, ед.; х2 - показатель численности персонала, занятого научными ИиР; х3 - объем затрат на научные исследования и разработки, млн. руб.; х4 - объем затрат на технологические инновации, млн. руб.; х5 - число организаций, ведущих подготовку аспирантов, ед.; х6 - Численность аспирантов, ед.; х7 - показатель уровня поступления патентных заявок на изобретения, ед.; х8 - по-

Таблицุ 1. Положение инновационной деятельности в ПФО в 2016 г.

\begin{tabular}{|c|c|c|c|c|c|c|}
\hline Показатель & $\begin{array}{c}\text { Организа- } \\
\text { ции, вы- } \\
\text { полнявшие } \\
\text { научные } \\
\text { ИиР, ед. }\end{array}$ & $\begin{array}{c}\text { Числен- } \\
\text { ность } \\
\text { персонала, } \\
\text { занятого } \\
\text { научными } \\
\text { ИиР, тыс. } \\
\text { чел. }\end{array}$ & $\begin{array}{c}\text { Внутренние } \\
\text { затраты на } \\
\text { научные ис- } \\
\text { следования } \\
\text { и разра- } \\
\text { ботки, млн. } \\
\text { руб. }\end{array}$ & $\begin{array}{c}\text { Затраты на } \\
\text { техноло- } \\
\text { гические } \\
\text { инновации, } \\
\text { млн. руб. }\end{array}$ & $\begin{array}{c}\text { Число ор- } \\
\text { ганизаций, } \\
\text { ведущих } \\
\text { подготовку } \\
\text { аспирантов, } \\
\text { ед. }\end{array}$ & $\begin{array}{c}\text { Иннова- } \\
\text { ционная } \\
\text { активность } \\
\text { организа- } \\
\text { ций }\end{array}$ \\
\hline Республика Башкортостан & 74 & 8008 & 8854,4 & 8618,7 & 28 & 7,3 \\
\hline Республика Марий Эл & 8 & 281 & 167,7 & 167,6 & 3 & 5,9 \\
\hline Республика Мордовия & 25 & 927 & 798,8 & 775,5 & 4 & 13,4 \\
\hline Республика Татарстан & 113 & 12189 & 12569,2 & 11977,3 & 36 & 21,3 \\
\hline Удмуртская Республика & 34 & 1800 & 1102,9 & 1092,9 & 8 & 7,6 \\
\hline Чувашская Республика & 25 & 1487 & 1528,7 & 1496,2 & 4 & 24,5 \\
\hline Пермский край & 68 & 10304 & 14005,6 & 12206,8 & 14 & 7,9 \\
\hline Кировская область & 23 & 1672 & 1452,7 & 1444,4 & 7 & 9,6 \\
\hline Нижегородская область & 97 & 41427 & 77751,7 & 66317,1 & 23 & 12,8 \\
\hline Оренбургская область & 35 & 1404 & 700,8 & 669,1 & 8 & 7,1 \\
\hline Пензенская область & 28 & 4690 & 3793,6 & 3679,5 & 4 & 20,1 \\
\hline Самарская область & 71 & 9615 & 11842,3 & 11641,9 & 20 & 3,9 \\
\hline Саратовская область & 56 & 5364 & 4387,7 & 4242,0 & 14 & 4,8 \\
\hline Ульяновская область & 32 & 5136 & 8778,9 & 7887,1 & 6 & 3,6 \\
\hline
\end{tabular}


Таблица 2. Интегральный индекс экономической безопасности регионов ПФО за 2016 гг.

\begin{tabular}{|c|c|c|c|c|c|c|c|c|c|c|c|c|c|c|}
\hline Регион & 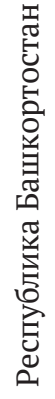 & 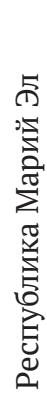 & 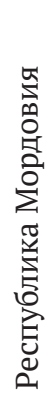 & 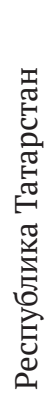 & 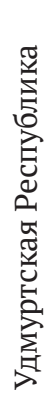 & 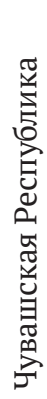 & 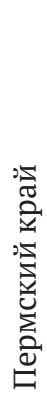 & 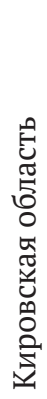 & 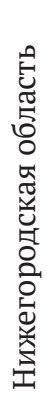 & 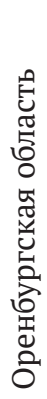 & 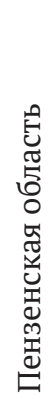 & 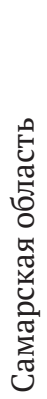 & 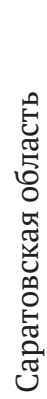 & 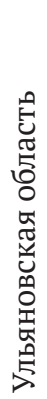 \\
\hline $\begin{array}{c}\text { Интегральный } \\
\text { индекс }\end{array}$ & \begin{tabular}{l}
\multirow{\sigma}{*}{} \\
$\stackrel{n}{\sigma}$ \\
$\sigma$ \\
$\sigma$
\end{tabular} & $\begin{array}{l}\text { o } \\
0 \\
\text { J్t } \\
\sigma \\
0\end{array}$ & \begin{tabular}{l} 
a \\
$\infty$ \\
\multirow{2}{*}{} \\
b \\
0
\end{tabular} & 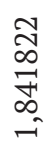 & 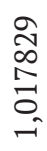 & $\begin{array}{l}\infty \\
\text { m } \\
\text { } \\
\infty \\
\infty \\
0\end{array}$ & 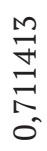 & \begin{tabular}{l} 
In \\
\multirow{2}{N}{} \\
\multirow{Z}{*}{} \\
0 \\
0
\end{tabular} & 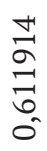 & 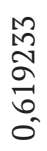 & $\begin{array}{l}\text { Nิ } \\
\text { ర్ } \\
0 \\
0\end{array}$ & 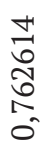 & $\begin{array}{l}\text { తె } \\
\infty \\
10 \\
0 \\
1 \\
1\end{array}$ & $\begin{array}{l}\overrightarrow{8} \\
\text { ำ } \\
\text { ㅇ. }\end{array}$ \\
\hline
\end{tabular}

казатель выданных патентов на изобретения, ед.; х9 - показатель инновационной активности организаций.

Изучив теоретические аспекты вопроса определения коэффициента корреляции, мы пришли к выводу, что значение этого показателя колеблется от «-1» до «+1». Чем ближе значение к +1 или -1, тем теснее корреляционная связь.

Полученные результаты факторного анализа влияния инновационной составляющей на уровень экономической безопасности регионов ПФО можно представить следующим образом (табл. 3).

Как видно, показатель r1=0,54, что указывает на умеренную положительную корреляцию между уровнем экономической безопасности региона и показателем количества организаций, выполнявших научные исследования и разработки. В 2015 году в ПФО количество организаций, выполнявших научные исследования и разработки составляло 715 ед. в 2014 году - 619 ед. увеличение количества организаций объясняется инвентаризацией организаций сектора исследований и разработок, проведенной в соответствии с приказом Федеральной службы государственной статистики от 01.12.2015 № 596.

Но несмотря на рост до 2015 года, в 2016 году данный показатель снизился с 715 до 689. Данное сокращение объема организаций научно-исследовательской направленности объясняется проводимой федеральными органами власти политикой по оптимизации подведомственной сети научных организаций. Реформирование проводилось в рамках укрупнения и ликвидации организаций, которые практически прекратили научную деятельность. Далее проанализируем зависимость экономической безопасности и показателя численности персонала, занятого научными исследованиями и разработками, который составил $\mathrm{r} 2=0,72$.

Таблица 3. Влияние инновационной составляющей на уровень экономической безопасности регионов ПФО

\begin{tabular}{|l|c|c|c|}
\hline \multicolumn{1}{|c|}{ Показатели } & $\begin{array}{c}\text { Сильная } \\
\text { корреляцион- } \\
\text { ная связь }\end{array}$ & $\begin{array}{c}\text { Умеренная } \\
\text { корреляцион- } \\
\text { ная связь }\end{array}$ & $\begin{array}{c}\text { Связи между } \\
\text { перактическии } \\
\text { нет }\end{array}$ \\
\hline Количество организаций, выполнявших научные ИиР & & 0,54 & \\
\hline Численность персонала, занятого научными ИиР & 0,72 & & 0,34 \\
\hline Затраты на научные исследования и разработки & & & \\
\hline Затраты на технологические инновации & 0,85 & & 0,44 \\
\hline Число организаций, ведущих подготовку аспирантов & & & \\
\hline Численность аспирантов & & 0,48 & \\
\hline Уровень поступления патентных заявок на изобретения & & 0,51 & \\
\hline Выданные патенты на изобретения & & & \\
\hline Инновационная активность организаций & 0,75 & & \\
\hline
\end{tabular}


Из результатов расчетов видно, что теснота связи указывает на тесную положительную корреляцию. Высокий уровень рисков экономической безопасности регионов во многом связан с недоиспользованием потенциала персонала, занятого научными исследованиями и разработками. По мнению ученых данной сферы, обеспечение высокого уровня экономической безопасности не может быть достигнуто без повышения внимания к уровню использования трудовых ресурсов и в первую очередь ученых и специалистов сфере научных исследований и разработок.

Далее проанализируем зависимость уровня экономической безопасности и объема затрат на научные исследования и разработки, который составил $r 3=0,34$.

По результатам расчетов видно, что наблюдаемся умеренная положительная корреляционная связь. Данное обстоятельство вызвано тем, что увеличение затрат на научные исследования и разработки ведет к повышению уровня инновационной активности, что позволит повысить конкурентоспособность регионов и в целом повысить экономические темпы роста, что ведет к повышению доходов населения, что в конечном счете скажется на социальной составляющей экономической безопасности регионов.

Далее рассмотрим зависимость экономической безопасности от уровня затрат на технологические инновации, который составил r4=0,85.

Показатель указывает на сильную корреляцию между переменными. Повышение экономической безопасности невозможно без затрат на технологические инновации, которые позволят повысить конкурентоспособность отечественных товаров на мировых рынках и как результат перейти на новый уровень инновационного развития региона.

Далее рассмотрим зависимость экономической безопасности и объема организаций, ведущих подготовку аспирантов, который составил r5 $=0,44$.

По данным расчетов видно, что зависимость экономической безопасности ПФО и числа организаций, ведущих подготовку аспирантов имеет умеренную зависимость. Далее рассмотрим зависимость уровня экономической безопасности и численности аспирантов региона, который составил $\mathrm{r} 6=0,33$.

Из полученного значения коэффициента корреляции видно, что зависимость слабая.
Далее рассмотрим уровень зависимости экономической безопасности ПФО и поступления патентных заявок на изобретения, который составил $r=0,48$.

По результатам расчетов видно, что зависимость между показателями имеет умеренный характер. Далее определим зависимость уровня экономической безопасности ПФО и показателя выданных патентов на изобретения, который составил $r 8=0,51$.

Результат расчетов свидетельствует о умеренной зависимости.

Далее рассчитаем коэффициент корреляции между уровнем экономической безопасности и показателя инновационной активности организаций, который составил $\mathrm{r} 9=0,75$.

По результатам расчетов видно, что зависимость между переменными сильная положительная. Использование инноваций в производственной деятельности обеспечивает высокий уровень конкурентоспособности товаров, производимых в регионе, что позволяет даже в современных условиях жесткой конкуренции занять свою нишу на рынке, увеличивая экспорт высокотехнологической продукции. Так же использование инноваций в производственной сфере ведет к повышению производительности труда. Что приводит к повышению экономического роста региона и уровню доходов населения. Что так же сказывается на социальной составляющей экономической безопасности региона.

\section{Выводы}

Инновационная составляющая коренным образом влияет на уровень экономической безопасности региона. Наибольшее влияние инновационной составляющей на экономическую безопасность региона оказывают показатели численности персонала, занятого научными разработками и исследованиями, объем затрат на технологические инновации и инновационная активность организаций.

На основании вышесказанного, основными направлениями по повышению экономической безопасности регионов ПФО можно выделить следующие: увеличение численности персонала, занятого научными исследованиями и разработками; повышение государственной поддержки организаций, занимающихся производством и внедрением высоких технологий; повышение инновационной активности организаций. 


\section{Библиографический список}

1. Колемаев В. А., Староверов О.В., Турундаевский В.Б. Теория вероятности и математическая статистика. Москва. 1991.400 с.

2. Куниман М.В. Экономическая безопасность: учебное пособие. Москва. 2016. 152 с.

3. Соколова Г.Н., Марков А.В. Факторный анализ развития регионов и выявление корреляционной взаимосвязи// Научное обозрение. 2017. № 21. С. 121-124.

4. Соколова Г.Н., Ладыкова Т.И. Экономическая безопасность региона: сущность и пути обеспечения // Научное обозрение. 2017. № 21. С. 107-110.

5. Федеральная служба государственной статистики «Регионы России. Социально-экономические показатели», 2017 г. URL: http://www.gks.ru/free_doc/doc_2017/region/reg-pok17.pdf (дата обращения 25.08.2018)

Поступила в редакцию 31.08.2018 